\title{
Centesimal and mineral analysis of cupcakes base meal of leaves and stems of ora-pro-nobis (Pereskia aculeata)
}

\section{Luciele Milani Zem}

Cristiane Vieira Helm
Departamento de Fitotecnia e Fitossanitarismo. Universidade Federal do Paraná, Curitiba, PR, Brasil

E-mail: luzem@uol.com.br

Laboratório de Produtos Florestais Não Madei-ráveis. Empresa Brasileira de Pesquisa Agropecuá-ria.Embrapa Florestas, Colombo, PR, Brasill

E-mail: cristiane.helm@embrapa.br

Katia Christina ZuffellatoRibas

Departamento de Botânica. Universidade Federal do Paraná, Curitiba, PR, Brasill E-mail: kazu@ufpr.br

Departamento de Fitotecnia e Henrique Soares Koehler
Fitossanitarismo. Universidade Federal do Paraná, Curitiba, PR, Brasill

E-mail: koehler@ufpr.br

Recebido em: 8 jun. 2017. Aceito: 10 jul. 2017.

DOI: http://dx.doi.org/10.21674/2448-0479.32.428-446

\section{Abstract}

Food and nutrition are basic requirements for the ascension and protection of human health. However, food education is a slow process. Therefore, the use of unconventional vegetables as food, such 
as Pereskia aculeata, a cactaceae rich in essential proteins and used to fight against malnutrition is encouraged. The objectives of this study were to determine the bromatological composition of cupcakes made of leaves and stems of $P$. aculeata, as well as to characterize the nutrients and minerals present therein. Four recipes were tested: natural cupcake; with dry leaves flour; with leaf+stem flour; and with fresh leaves. The levels of moisture, ashes, proteins, dietary fibers, lipids, total carbohydrates, total caloric value, and minerals were determined. Cupcakes made with $P$. aculeata flour are a consuming alternative with excellent nutritional value. Cupcakes prepared with dry leaf flour presented high protein $(7.69 \%)$ content and those with leaf meal+stem presented a higher dietary fiber content (8.55\%). However, both presented satisfactory results for the phosphorus, sodium, magnesium, copper, and zinc minerals. Therefore, the cupcakes with dry leaf flour and leaves+stem, due to their nutritional qualities, are the most suitable option for consumption.

Keywords: Cactaceae. Non-conventional food plant. Cake. Chemical composition. Nutritional value.

\section{Resumo}

\section{Análise mineral e centesimal de cupcake a base de farinha de folhas e caule de ora-pro- nobis (Pereskia aculeata)}

A alimentação e nutrição são requisitos básicos para ascensão e proteção da saúde do ser humano, no entanto a educação alimentar é um processo lento. Por isso do incentivo para o uso alimentar de 
PANCs como Pereskia aculeata, cactácea rica em proteínas e utilizada no combate à desnutrição. Os objetivos desse estudo foram determinar a composição bromatológica de cupcakes elaborados com farinha de folhas e caules de $P$. aculeata, caracterizando os nutrientes e minerais presentes. Foram testadas quatro receitas: cupcake natural; com farinha de folhas secas; com farinha de foIhas+caule; com folhas frescas. Foram determinados os teores de: umidade, cinzas, proteínas, fibras alimentares, lipídeos, carboidratos totais, valor calórico total e minerais. Os cupcakes elaborados com farinha de $P$. aculeata são uma alternativa de consumo com excelente valor nutricional. Os cupcakes preparados com farinha de foIhas secas apresentaram alto teor de proteínas $(7,69 \%)$ e os de farinha de folhas+caules maior teor de fibras alimentares (8,55\%). No entanto, ambos apresentaram resultados satisfatórios para os minerais fósforo, sódio, magnésio, cobre e zinco. Desta forma, os cupcakes com farinha de folhas secas e folhas+caule, devido suas qualidades nutricionais, são os mais indicados para consumo.

Palavras-chave: Cactaceae. Planta alimentícia nãoconvencional. Bolo. Composição química. Valor nutricional.

\section{Introduction}

Proper food and nutrition are some of the basic requirements for health's ascension and protection, enabling a better human growth and development, with life quality and citizenship (SILVA; CAMARGO, 2006). An insufficient ingestion of some nutrients affects one in every four persons in the world, mostly from underdeveloped countries. Consequently, several foods are used to strengthen the Rev. Elet. Cient. UERGS, , v. 3, n. 2, p. 428-446, 2017 
diet, such as wheat flour, salt, milk, butter, and sugar (SILVA JÚNIOR et al., 2010). Although a nutritional education would be the ideal method, it is a slow process, requiring several years to present results. The use of drug supplements, however, is the quickest way to solve the problem of nutritional deficiency, but its results are not always the ones we expect, since they usually have an unpleasant taste and present side effects (FISBERG, 1996).

In this context, the purpose of encouraging the use of unconventional plants and/or vegetables (PANCS) as food, such as the P. aculeata Mill., is to change the relation man versus food, including, therefore, a more nutritious, healthier, and tastier food in our diet (ROCHA et al., 2008). Pereskia aculeata, popularly known as orapro-nobis, which in Latin means, "pray for us," is a plant that belongs to the Plantae kingdom nd Cac-taceae family. It has a high use potential and is grown marginally and rudimentary (KINUPP; BARROS, 2008).

This species is found from Bahia down to Rio Grande do Sul, and it is considered a rustic and resilient plant, growing in different kinds of soil. It is a fact that it can be used to fight malnutrition and for veterinary purposes, including as food for cattle and other animals (SARTOR et al., 2010). It is also rich in essential amino acids and vegetable protein of about $25 \%$ to $35 \%$ in dry base. However, its scientific studies are scarce (KINUPP; LORENZI, 2014).

We believe that the consumption potential of this species in a daily food diet is extremely important because, besides having nutrients for a healthy diet, with the increase of its consumption, its grown would automatically increase too (RIBEIRO et al., 2014). The absence of toxicity in its leaves makes of the $P$. aculeata an important source for human nutrition. It can be consumed as stews and soups, 
as flour to make pies, doughs, cookies, breads, and cakes, all with a high protein level (OLIVEIRA et al., 2015; TAKEITI et al., 2009).

The small cakes called cupcakes were created in UK in 1828. They are also known as fairy cakes because this cake recipe is measured in cups and then baked. The creation of cupcakes was a revolutionary fact because it reduced the cooking time and was easy to measure the ingredients that were used (SMITH, 2004).

The consumption of unconventional vegetables like the $P$. aculeata is still not very encouraged. Therefore, we need to take action to in-crease its consumption (ROCHA et al., 2008). The lack of information of the public regarding the nutritional value of the $P$. aculeata and its preparation poses a natural restriction to its consumption (ROCHA et al., 2008).

Therefore, and with the purpose of offering a product with greater nutritional quality and that is accessible to most of the public, we engaged in studying the bromatological composition of cupcakes made with $P$. aculeata leaf and stem flour and dry leaves, with the purpose of identify and quantify the nutrients present in the species.

\section{Material and Methods}

The vegetal material of Pereskia aculeata was collected in $\mathrm{Cu}$ ritiba-PR, on the coordinates $25^{\circ} 38^{\prime} 29.28^{\prime \prime}$ of South latitude and $49^{\circ} 29^{\prime} 61.47$ " of West longitude. According to the Köppen classification, the region's climate is of the Cfb type, that is, a climate classified as moist temperate, with a mean temperature of the hotter month above $10^{\circ} \mathrm{C}$, with smooth summers and winters with frequent frosts and a tendency of rain concentration in the summer months, 
however, without a defined dry season. Dry samples of the species were deposited in the Federal University of Paraná's (UFPR) herbarium, receiving the classification no UPCB 75848.

Pereskia aculeata leaves and stems were collected to make flour, which would be used in food processing. The vegetable material was duly washed three times in distilled water and placed in storage at $60^{\circ} \mathrm{C}$ for 24 hours. To make $100 \mathrm{~g}$ of flour, $1 \mathrm{~kg}$ of $P$. aculeata leaves was necessary.

To make the cupcakes, the four following recipes were tested: cupcake without $P$. aculeata flour addition (natural cupcake); using dry leaf flour (CF); cupcake made with dry leaf+stem flour (CFC); cupcake made with fresh leaves (CFR), using $36 \mathrm{~g}$ of flour in each mixture (Table 1); and then it was ground and stored in a freezer at $20^{\circ} \mathrm{C}$ for future food producing, excepting the dry leaves. To make the dough, we used ingredients like wheat flour, eggs, butter, sugar, vanilla essence, and baking powder, which were bought in commercial establishments of the city of Curitiba (PR), at the quantities described in Table 1.

Table 1. Ingredients used to make natural cupcake (CN), and cupcakes with Pereskia aculeata leaf flour (CF), with leaf+stem flour (CFC), and with fresh leaves (CFR), Curitiba (PR), 2015.

\begin{tabular}{|c|c|c|c|c|c|}
\hline \multirow{2}{*}{ Ingredients } & & CN & CF & CFC & CFR \\
\hline & \multicolumn{5}{|c|}{ Quantity } \\
\hline Wheat Flour & $\mathrm{g}$ & 120 & 84 & 84 & 84 \\
\hline Eggs & g & 150 & 150 & 150 & 150 \\
\hline Butter & g & 150 & 150 & 150 & 150 \\
\hline Vanilla Essence & $\mathrm{ml}$ & 7 & 7 & 7 & 7 \\
\hline Baking Powder & g & 12 & 12 & 12 & 12 \\
\hline Pereskia aculeata & $\mathrm{g}$ & - & 36 & 36 & 36 \\
\hline
\end{tabular}


The bromatological analyses were performed at the Laboratory of Non-Wood Forest Products of Embrapa Forests, located in Colombo (PR), and performed according to the Official Methodologies of Adolfo Lutz Institute (BRASIL, 2008) and the data were expressed in percentages in dry base (determined by the greenhouse method until constant weight). The analyses were performed in triplicate so each data would correspond to the mean of three repetitions.

As to the nutritional composition, excepting the total dietary fibers and total carbohydrates, all other elements (moisture, ashes, lipids, and proteins) were performed in triplicate, according to the official methodology of Adolfo Lutz Institute (SARTOR et al., 2010). The samples' moisture was deter-mined in about $5 \mathrm{~g}$ of sample, which remained for 12 hours in a greenhouse at a temperature of $105^{\circ} \mathrm{C}$. The ashes, representing the total of minerals, were determined by calcining about $2 \mathrm{~g}$ of sample in the muffle at $550^{\circ} \mathrm{C}$ for three hours. The percentage of ashes was obtained through the multiplication of the sample ashes' mass (g) by 100 and then by dividing this result by the sample's mass $(\mathrm{g})$.

The lipids were determined in $1.5 \mathrm{~g}$ of sample using ethyl ether as an extracting solvent during the period of six hours, in Extrator Soxhlet. The obtained ethereal extract was placed in a greenhouse set in $70^{\circ} \mathrm{C}$ for one hour to remove the remains of the solvent, followed by its cooling in a dry environment and then weighted. The level of lipids was calculated through the multiplication by 100 of the lipid mass and this result was divided by the sample's mass (g). Total proteins were obtained in $0.5 \mathrm{~g}$ of sample through the micro Kjeldahl method, which quantifies the sample's level of total nitrogen. The protein percentage was calculated through the multiplication of the total nitrogen percentage by the conversion factor of 6.25 . 
The dietary fibers were determined through the gravimetric enzymatic method with $1 \mathrm{~g}$, which consists in hydrolyzing starch to obtain the proteins through the use of the protease, heat stable alpha-amylase, and amyloglucosidase (glucoamylase) enzymes.

The total caloric value, in $\mathrm{kcal}$, was determined considering the con-version factor of 4.0 for proteins and carbohydrates, and 9.0 for lipids. The macronutrient and micronutrients minerals were determined by the Laboratory of Soil Chemistry and Fertility, of the Federal University of Paraná, in Curitiba (PR).

\section{Results and Discussion}

The chemical composition data of the cupcakes in dry base showed that the variables ashes, lipids, proteins, and fibers presented a significant difference at the level of $5 \%$ and $1 \%$ of probability (Table 2).

Moisture is an important quality index because it can affect the sample's characteristics and the product's preservation, and its high level allows the activity of microorganisms and enzymes, which changes the sample's sensory characteristics (MORGANO et al., 2008). According to the results obtained, the cupcakes did not present any significant difference, with moistures of $74.51 \%, 75.18 \%$, $74.31 \%$, and $80.95 \%$ for the natural cupcakes, and for the cupcakes with leaf flour, with leaf+stem flour, and fresh leaves, respectively.

When we compare the moisture of this study's cupcakes with the cakes made by Rosa et al. (2011) which included ora-pro-nobis fresh leaves in their dough, we noticed that the moisture of the cupcakes made here was superior to the cakes of the aforementioned authors, which obtained a moisture that varied from $22.41 \%$ to 
$33.63 \%$. Regarding the ashes, the higher level was found in the natural cupcake $(2.30 \%)$ and in the one made with dry leaf flour $(2.37 \%)$, while the cupcakes made with fresh leaves presented the lower level $(0.67 \%)$ (Table 2$)$. Since the ashes are linked to the presence of mineral salts, we also noticed higher levels of most minerals in the natural and in the dry leaf flour cupcakes, and lower mineral levels in the fresh leaf cupcake (Table 2).

Table 2. Percentage of ashes, lipids, fibers, total carbohydrates (CT), and total caloric value (VCT - kcal $100 \mathrm{~g}-1$ ) of the cupcakes with and without addition of Pereskia aculeata flours or fresh leaves, Curitiba (PR), 2015

\section{DRY BASE}

\begin{tabular}{llllll}
\hline & CN $^{\mathrm{a}}$ & CF $^{\mathbf{b}}$ & CFC $^{\mathbf{c}}$ & CFR $^{\mathbf{d}}$ & $\begin{array}{c}\text { Variation } \\
\text { Coefficient (\%) }\end{array}$ \\
\hline Ashes (\%) & $2.30 \mathrm{a}$ & $2.37 \mathrm{a}$ & $1.47 \mathrm{bc}$ & $0.67 \mathrm{c}$ & 10.61 \\
\hline Lipids (\%) & $24.70 \mathrm{~b}$ & $26.54 \mathrm{~b}$ & $32.46 \mathrm{a}$ & $34.94 \mathrm{a}$ & 8.36 \\
Proteins (\%) & $6.58 \mathrm{a}$ & $7.69 \mathrm{a}$ & $7.21 \mathrm{a}$ & $6.17 \mathrm{a}$ & 8.73 \\
Fibers (\%) & $5.88 \mathrm{~b}$ & $5.41 \mathrm{~b}$ & $8.55 \mathrm{a}$ & $4.50 \mathrm{~b}$ & 9.94 \\
CT (\%) & 60.54 & 57.99 & 50.31 & 53.72 & \\
\hline VCT (kcal 100 $\mathbf{~ g}^{-1}$ ) & 490.78 & 501.58 & 522.22 & 554.02 & \\
\hline
\end{tabular}

Statistically, means followed by the same letter in the line are not different from the $5 \%$ level of significance. ${ }^{a}$ Natural cupcake (CN); ${ }^{b}$ Cupcake with leaf flour (CF); ${ }^{\mathrm{c} C u p c a k e ~ w i t h ~ l e a f+s t e m ~ f l o u r ~(C F C) ; ~}{ }^{\mathrm{d} C u p c a k e}$ with fresh leaves (CFR).

Rosa et al. (2011) made cakes with different $P$. aculeata in natura leaf percentages, and the one made with $30 \%$ of fresh leaves presented the higher ash level of $2.59 \%$, a value that is similar to the dry leaf flour cupcake (2.37\%) found herein. A diet's lipids are important to the growth, development, and maintenance of health, and their level varies according to the type of food, from which fruits and leafy vegetables are among the foods with lower levels $(0.1-1.2 \%$ of the fresh composition) (AUED-PIMENTEL; ZENEBON, 2009). 
The natural cupcakes and the ones made with $P$. aculeata presented lipid values, in dry base, of $24.70 \%$ to $34.94 \%$, values that are superior when compared with the work of Rosa et al. (2011) who made the cakes with the addition of different percentages of fresh Pereskia leaves, resulting in a lipid level variation from $10.38 \%$ to $13.07 \%$. The higher lipid level presented herein is probably related to the other ingredients used to prepare the recipes.

The high lipid level found in the analyzed cupcakes is a negative aspect, since these foods cannot be used in hypocaloric diets and with lipid restriction (ROCHA et al., 2008). The level of proteins seen in the cupcakes made with dry leaf flour was numerically superior to the other cupcakes $(7.69 \%)$, even though there was no statistic difference in comparison with the natural cupcake $(6.58 \%)$, with the leaf+stem flour cupcake $(7.21 \%)$, and with the fresh leaf cupcake (6.17\%) (Table 2).

The cupcakes, when made with leaf+stem flour and dry leaves, presented a protein level increase of approximately $9 \%$ to $14 \%$, respectively. Silva Júnior et al. (2010), studied breads with 5\% and $10 \%$ of leaf flour of $P$. aculeata and presented an increase of $3 \%$ to $6 \%$. The cupcakes with and without $P$. aculeata addition presented protein levels inferior to the work of Rosa et al. (2011) whose purpose was to increase the nutritional quality of cakes with $10 \%$ (11.42\%), 20\% (10.73\%), 30 (11.03\%), and 40\% (12.05\%) of P. aculeata fresh leaves. However, in these authors' work, no significant difference was found in these treatments in comparison with conventional cakes (11.53\%). Herein, the same response pattern was found, when the cupcakes with $P$. aculeata present no difference from the natural cupcakes (Table 2).

According to the National Sanitary Surveillance Agency (2005) an adult should daily ingest about $50 \mathrm{~g}$ of proteins (daily), and a food 
can be considered protein-rich when, in a 100-g portion, it provides about $20 \%$ of the daily intake. Therefore, considering the results analyzed herein, the cupcakes would provide between 6 to $7 \mathrm{~g}$ of an adult's daily needs. The results obtained in the chemical classification of the foods presented a higher percentage of dietary fibers in the $P$. aculeata leaf+stem flour cupcakes, with $8.55 \%$ (Table 2). According to the Ministry of Health (2005) the daily recommendation of fiber intake for an adult is of $25 \mathrm{~g} \mathrm{a} \mathrm{day}^{-1}$; ergo, the daily intake of $100 \mathrm{~g}$ of the cupcake with addition of leaf+stem flour would correspond to, approximately, $34.20 \%$ of the daily recommendation.

Dietary fibers affect the bowel movement speed, the colon $\mathrm{pH}$, and the production of subproducts of important physiological functions (BERNAUD; RODRIGUES, 2013). Usually, a low dietary fiber intake is liked to constipation and weight gain (VITOLO et al., 2007).

A food may be considered fiber-rich if it has a minimum of $6 \%$ for solids of the product (ANVISA, 2005). Therefore, the natural cupcake, as well as the cupcakes made with dry leaf flour and fresh leaves cannot be considered a good fiber source. Fiber-rich foods have a lower energetic density when compared with fat-rich foods. Therefore, the lack of energy (calories) in the organism could be satisfied by fiber-rich foods (BERNAUD; RODRIGUES, 2013).

Differently from the results hereof, the cakes made with different percentages of $P$. aculeata fresh leaves presented a fiber level increase with the cakes' leaf percentage increase. Actually, an addition of just $10 \%$ of leaves increased the fiber level in $227.93 \%$ in comparison with the cake that did not use any leaf (ROSA et al., 2011).

Regarding the total caloric value, we noticed that the cupcakes presented a value between $490.78 \mathrm{kcal} 100 \mathrm{~g}^{-1}$ and $554.2 \mathrm{kcal} 10 \mathrm{~g}$ 1 . This means that, in a regular diet of $2000 \mathrm{Kcal}$, about $100 \mathrm{~g}$ of the 
cupcake would represent from $24.54 \%$ to $27.70 \%$ of the daily recommendation. The intake of foods with low caloric value is indicated for health and to control obesity (ALMEIDA et al., 2014). However, the entire food context should be analyzed, because a food with low total caloric value is not always the most indicated for consumption due to its inferior nutritional value. Consequently, we noticed that the natural cupcake, although it has the lower total caloric value (490.78 kcal $100 \mathrm{~g}^{-1}$ ), when compared with the other cupcakes, it presents inferior nutritional values.

Regarding the carbohydrate level, the analyzed cupcakes present values between $50.31 \%$ and $60.54 \%$ (Table 2 ). The minimum quantity of carbohydrates necessary is of $130 \mathrm{~g} \mathrm{a} \mathrm{day}^{-1}$ for men and women over 19 years old (ANVISA, 2005). Consequently, the intake of $100 \mathrm{~g}$ of the cupcakes would provide between $38.70 \%$ and $46.57 \%$ of an adult's daily recommendations. On the other hand, the minerals exert an important task in the peculiar development and good health of the human body, and are essential for the good functioning thereof. However, their daily intake quantity is usually low (GONDIM et al., 2005).

The daily mean recommendation of the Dietary Reference Intakes (DRI) of some minerals for men and women between 9 and 70 years old is of $1,160 \mathrm{mg}$ of calcium; $975 \mathrm{mg}$ of phosphorus; $9.5 \mathrm{mg}$ for men and $13 \mathrm{mg}$ for women of iron; $360 \mathrm{mg}$ of magnesium for men and $300 \mathrm{mg}$ for women; $830 \mathrm{mg}$ of copper; $2 \mathrm{mg}$ of manganese; 9.5 $\mathrm{mg}$ of zinc for men and 8.5 for women; $1.3 \mathrm{mg}$ of sodium; $4.6 \mathrm{mg}$ of potassium (ANVISA, 2005). When we analyzed the cupcakes, the higher values of most evaluated minerals were found in the cupcakes made with dry leaf flour (Table 3).

Therefore, considering the daily mean recommendation, the intake of cupcakes made with dry leaf flour in the quantity of approx- 
imately $100 \mathrm{~g} \mathrm{a} \mathrm{day}^{-1}$ would satisfy in $23.20 \%$ the necessity of calcium; $67.24 \%$ of phosphorus; $7.89 \%$ of iron for men and $10.79 \%$ for women; $52.17 \%$ and $43.47 \%$ of magnesium for man and women, respectively; $11.53 \%$ of manganese; $79.69 \%$ and $71.30 \%$ of zinc for man and women, respectively; $0.22 \%$ of sodium, and, finally, $0.14 \%$ of potassium (Table 3).

Table 3. Levels of the phosphorus $(\mathrm{P})$, sodium $(\mathrm{Na})$, potassium $(\mathrm{K})$, magnesi-um $(\mathrm{Mg})$, calcium $(\mathrm{Ca})$, copper $(\mathrm{Cu})$, iron $(\mathrm{Fe})$, manganese $(\mathrm{Mn})$, and zinc $(\mathrm{Zn})$ minerals in the natural cupcake $(\mathrm{CN})$, and in the cupcakes with Pereskia aculeata leaf flour (CF), with leaf+stem flour (CFC), and with fresh leaves (CFR), Curitiba (PR), 2015.

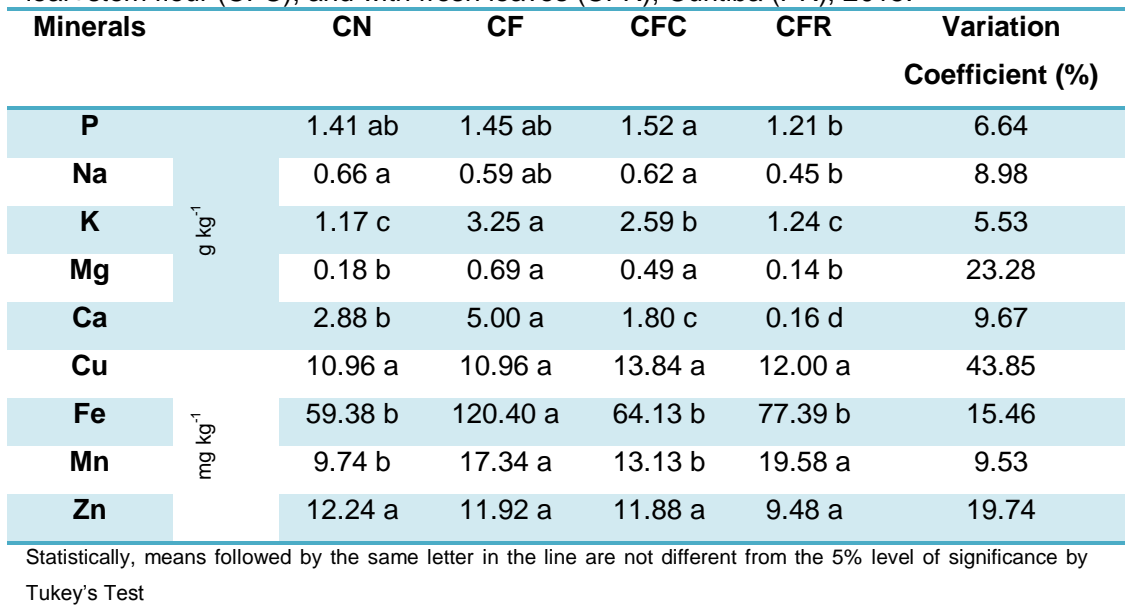

Analyzing the phosphorus, the cupcakes made with leaf+stem flour $\left(1.52 \mathrm{~g} \mathrm{~kg}^{-1}\right)$ are different only from the fresh leaf cupcakes $\left(1.21 \mathrm{~g} \mathrm{~kg}^{-1}\right)$. This low availability of phosphorus in vegetableoriginated foods is linked to how it is available in foods (GONÇALVES et al., 2007). Although the phosphorus acts with the calcium and play the role to keep bones, teeth, heart, and blood vessels in good shape, phosphorus-rich foods should be reduced (TELLES; BOITA, 2015). However, it is difficult to completely eliminate them, 
since these foods are also protein and calcium sources, which are essential to the organism (NERBASS et al., 2010).

Regarding the sodium, the natural cupcake presented a higher level of $0.66 \mathrm{~g} \mathrm{~kg}^{-1}$. However, it was not different from the dry leaf cupcake $\left(0.59 \mathrm{~g} \mathrm{~kg}^{-1}\right)$ and from the one made of leaf+stem flour $(0.62$ $\mathrm{g} \mathrm{kg}^{-1}$ ) (Table 3). The World Health Organization recommends a maximum daily intake of $2000 \mathrm{mg}$ of sodium (ANVISA, 2005). Therefore, all cupcakes are within the recommendation limit and may be considered satisfactory. Foods with low sodium level are the most indicated for a healthy nutrition, since sodium is a component of salt and there are several evidences that relate the excessive salt intake to hypertension (SATO et al., 2009).

The cupcake made with dry leaf flour was the one that presented a higher level of potassium, with $3.25 \mathrm{~g} \mathrm{~kg}^{-1}$. Potassium is a mineral that affects the muscles and nerves and that, in high levels, in humans, causes signs of muscle weakness, locked leg sensation, besides irregular heartbeats, which may manifest frequently. Therefore, it is important that the kidneys are healthy, since the excess of ingested potassium is filtered through the urine (TELLES; BOITA, 2015). Consequently, a diet rich in food of a high potassium level is important. However, we should be alert regarding it excess, since the desired level of plasma potassium should be lower than 5.5 mmolc $L^{-}$ 1 (TELLES; BOITA, 2015).

Analyzing the calcium levels, the dry leaf flour cupcake was the one that presented higher levels $\left(5.00 \mathrm{~g} \mathrm{~kg}^{-1}\right)$ when compared with the others. Calcium is an essential nutrient, and its daily necessity varies according to the age, being higher in periods of rapid growth (PEREIRA et al., 2009). Calcium shows its relevance in leafy vegetables, which may be considered a good source, satisfying the daily needs of $0.8 \mathrm{~g}$ (ANVISA, 2005). 
The analyzed cupcakes presented values of copper that vary from $10.96 \mathrm{mg} \mathrm{kg}^{-1}$ to $13.84 \mathrm{mg} \mathrm{kg}^{-1}$. Therefore, there was no significant difference between them (Table 3). Ergo, they can be considered rich in copper. This mineral has a regulating function on the immunological system, and in serious malnutrition cases, this micronutrient is reduced, which may result in immunological disorders and in the susceptibility increase to infections (MACÊDO et al., 2010). We should underscore that copper is a mineral that has its fair share in foods, and that its deficiency is quite rare in humans (KOURY; DONANGELO, 2007). This micronutrient's daily intake is of $900 \mu \mathrm{g}$ (SILVA JÚNIOR et al., 2010).

Regarding the iron, we know that its deficiency is the most common around the world, that it advances in several stages, and that it may happen due to the fact that the insufficient iron diet intakes prevail (KOURY; DONANGELO, 2007; SATO et al., 2009) Therefore, there should be more guidance regarding the intake increase of natural sources of iron and of foods that favor this mineral's absorption (SATO et al., 2009). The iron levels of the analyzed foods were superior in the leaf flour cupcake, with $120.40 \mathrm{mg} \mathrm{kg}^{-1}$.

Manganese is important because it is used in energy production. Cupcakes made with $P$. aculeata leaf flour presented $17.34 \mathrm{mg}$ $\mathrm{kg}^{-1}$ of manganese and were not different from the ones made with fresh leaves, with $19.58 \mathrm{mg} \mathrm{kg}^{-1}$ of $\mathrm{Mn}$. Zinc is a mineral that is spread all over the human body but in small dosages. Its deficiency is related to serious pathological cases that are manifest mostly due to nutritional deficiency (HAMBIDGE et al., 2008). To fulfill these needs, the main food sources are bovine meets, fishes, poultry, milk, cheeses, seafood, wholegrain cereals, wheat germ, beans, nuts, almonds, and pumpkin seed (DOMEN et al., 2008). 
The zinc daily recommendation is of $8 \mathrm{mg}$ for women and 11 mg for men (ANVISA, 2005). According to the results obtained herein, all analyzed cupcakes can be considered good zinc sources, and there was not difference between them (Table 4).

\section{Conclusion}

At last, we want to underscore that the cupcakes made with Pereskia aculeata flour are a consumption alternative with functional properties and with an excellent nutritional value, considering that the species is a protein-rich vegetable and that it is used to fight malnutrition. And since it presents similar results for the phosphorus, sodium, magnesium, copper, and zinc minerals, with good nutritional qualities, besides presenting a good quantity of fibers and proteins, the cupcakes made with Pereskia aculeata dry leaves and dry leaf+stem flour are the most indicated for consumption.

\section{References}

ALMEIDA; M. E. F. et al. Caracterização química das hortaliças não-convencionais conhecidas como ora-pro-nobis. Bioscience Journal, v. 30, n. 1, p. 431-439, 2014.

AGÊNCIA NACIONAL DE VIGILÂNCIA SANITÁRIA. Portaria no 27 Informação Nutricional complementar. Brasília, DF: ANVISA, 2005.

ASSUNÇÃO, M. C. F.; SANTOS, I. S. Efeito da fortificação de alimentos com ferro sobre anemia em crianças: um estudo de revisão. Caderno Saúde Pública, v. 23, n. 2, p. 269-281, 2007. 
AUED-PIMENTEL, S.; ZENEBON, O. Lipídeos totais e ácidos graxos na informação nutricional do rótulo dos alimentos embalados: aspectos sobre legislação e quantificação. Revista do Instituto Adolfo Lutz, v. 68, n. 2, p. 167-181, 2009.

BERNAUD, F. S. R.; RODRIGUES, T. C. Fibra alimentar - Ingestão adequada e efeitos sobre a saúde do metabolismo. Arquivos Brasileiros de Endocrinologia \& Metabologia, v. 57, n. 6, p. 397-405, 2013.

BRASIL. INSTITUTO ADOLFO LUTZ. Procedimentos e determinações gerais. In: LUTZ, I. A. Métodos Físico-químicos para análise de alimentos. 4⿳亠丷a edição/1ª edição digital. São Paulo: Instituto Adolfo Lutz, v. 1, 2008. Cap.4, p.1020.

DOMENE, S. M. A.; PEREIRA, T. C.; ARRIVILLAGA, R. K. Estimativa da disponibilidade de zinco em refeições com preparações padronizadas da alimentação escolar do município de Campinas. Revista Nutrição, v. 21, n. 2, p. 161-167, 2008.

FISBERG, M. Utilização de suplemento alimentar enriquecido com ferro na prevenção de anemia em pré-escolares. Revista de Pediatria Moderna, v. 32, p. 753-757, 1996.

GONÇALVES, G. S. et al. Disponibilidade aparente de fósforo em alimentos vegetais e suplementação da enzima fitase para tilápia-do-nilo. Revista Brasileira de Zootecnia, v. 36, n. 5, p. 1473-1480, 2007.

GONDIM, J. M. et al. Composição centesimal e de minerais em cascas de frutas. Ciência e Tecnologia de Alimentos, v. 25, n. 4, p. 825-827, 2005.

HAMBIDGE, M. K.; MILLER, L. V.; WESTCOTT, J. E. Dietary Reference Intakes for Zinc May Require Adjustment for Phytate IntakeBased upon Model Predictions. Journal of Nutrition, v. 138, p. 2363-2366, 2008. 
KINUPP, V. F.; BARROS, I. B. I. Teores de proteína e minerais de espécies nativas, potenciais hortaliças e frutas. Food Science Technology, v. 28, n. 4, p. 846-857, 2008.

KINUPP, V. F.; LORENZI, H. Plantas alimentícias não convencionais (PANC) no Brasil: guia de identificação, aspectos nutricionais e receitas ilustradas. São Paulo: Instituto Plantarum, 2014. 768 p.

KOURY, J. C.; DONANGELO, C. M. Homeostase de cobre e atividade física. Revista de Educação Física, v. 136, p. 47-56, 2007.

MACÊDO, E. M. C. et al. Efeitos da deficiência de cobre, zinco e magnésio sobre o sistema imune de crianças com desnutrição grave. Revista Paulista de Pediatria, v. 28, n. 3, p. 329-336, 2010.

MORGANO, M. A. et al. Determinação de umidade em café cru usando espectroscopia NIR e regressão multivariada. Ciência e Tecnologia de Alimentos, v. 28, n. 1, p. 12-17, 2008.

NERBASS, F. B. et al. Adesão e conhecimento sobre o tratamento da hiperfosfatemia de pacientes hiperfosfatêmicos em hemodiálise. Jornal Brasileiro de Nefrologia, v. 32, n. 2, p. 149-155, 2010.

OLIVEIRA, R. B. et al. Processamento de bolo com a planta Pereskia aculeata Mill. IX EPCC - Encontro Internacional de Produção Científica UniCesumar, n. 9, p. 4-8, 2015.

PEREIRA, G. A. P. et al. Cálcio dietético - estratégias para otimizar o consumo. Revista Brasileira de Reumatologia, v. 49, n. 2, p. 164-180, 2009.

RIBEIRO, P. A. et al. Ora-pro-nobis: cultivo e uso como alimento humano. Em extensão, v. 13, n. 1, p. 70-81, 2014.

ROCHA, D. R. C. et al. Macarrão adicionado de ora-pronobis (Pereskia aculeata Miller) desidratado. Alimentos e Nutrição, v. 19, n. 4 , p. 459-465, 2008. 
ROSA, L. et al. Elaboração e avaliação físico-química de bolo com folhas de ora-pro-nóbis in natura. In: I SEMINÁRIO DE INICIAÇÃO CIENTÍFICA DO INSTITUTO FEDERAL DO TRIÂNGULO MINEIRO, 2011, Uberlândia. Anais... 1ํㅗㄹ Seminário de Iniciação científica e Inovação Tecnológica do IFTM. Uberaba: IFTM, 2011. v. 1. p. 1-4.

SATO, A. P. S. et al. Consumo alimentar e ingestão de ferro de gestantes e mulheres em idade reprodutiva. Revista Latino Americano em Enfermagem, v. 18, n. 2, p. 113-121, 2009.

SARTOR, C. F. P. et al. Estudo da ação cicatrizante das folhas de Pereskia aculeata. Revista Saúde e Pesquisa, v. 3, n. 2, p. 149154, 2010.

SILVA, A. P. R.; CAMARGOS, C.N. Fortificação de alimentos: instrumento eficaz no combate a anemia ferropriva? Comum Ciência da Saúde, v. 17, n. 1, p. 53-61, 2006.

SILVA JÚNIOR, A. A. et al. Pão de ora-pro-nobis - um novo conceito de alimentação funcional. Agropecuária Catarinense, v. 23, n. 1, p. 35-37, 2010.

SMITH, A. F. The Oxford Encyclopedia of Food and Drink in America. 2 ed. Pennsylvania: Oxford University, 2004.

TAKEITI, C. Y. et al. Nutritive evaluation of a non-conventional leafy vegetable (Pereskia aculeata Miller). International Journal of Food Science and Technology, v.1, n.60, p.148-160, 2009.

TELLES, C.; BOITA, E. R. F. Importância da Terapia nutricional com ênfase no cálcio, fósforo e potássio no tratamento da doença renal crônica. Perspectiva, v. 39, n. 145, p. 143-154, 2015.

VITOLO, M. R.; CAMPAGNOLO, P. D. B.; GAMA, C. M. Fatores associados ao risco de consumo insuficiente de fibra alimentar entre adolescentes. Journal of Pediatric, v. 83, n. 1, p. 47-52, 2007. 